\title{
Optimization of PV powered SPD switchable glazing to minimise probability of loss of power supply
}

Aritra Ghosh

Technological University Dublin, a.ghosh@exeter.ac.uk

Brian Norton

Technological University Dublin, brian.norton@tudublin.ie

Follow this and additional works at: https://arrow.tudublin.ie/dubenart

Part of the Civil and Environmental Engineering Commons, and the Power and Energy Commons

\section{Recommended Citation}

Aritra Ghosh, Brian Norton, Optimization of PV powered SPD switchable glazing to minimise probability of loss of power supply, Renewable Energy, Volume 131, 2019, Pages 993-1001, ISSN 0960-1481, DOI:

10.1016/j.renene.2018.07.115.

This Article is brought to you for free and open access by the Dublin Energy Lab at ARROW@TU Dublin. It has been accepted for inclusion in Articles by an authorized administrator of ARROW@TU Dublin. For more information, please contact arrow.admin@tudublin.ie, aisling.coyne@tudublin.ie,gerard.connolly@tudublin.ie.

Funder: Higher Education Authority, Ireland

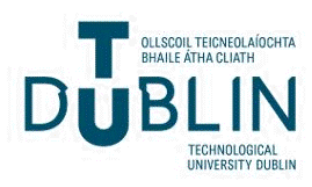




\title{
Optimization of PV powered SPD switchable glazing to minimise probability of loss of power supply
}

\author{
Aritra Ghosh ${ }^{\mathrm{a}, \mathrm{b},{ }^{*}, \text { Brian Norton }}{ }^{\mathrm{a}}$ \\ a Dublin Energy Lab, Dublin Institute of Technology, Dublin, Ireland \\ ${ }^{\mathrm{b}}$ Environmental and Sustainability Institute, University of Exeter, Penryn, Cornwall, UK
}

\section{A R T I C L E I N F O}

\section{Article history:}

Received 17 January 2018

Received in revised form

20 May 2018

Accepted 23 July 2018

Available online 26 July 2018

\section{Keywords:}

Suspended particle device (SPD)

Electrochromic (EC)

Loss of Power Supply Probability (LPSP)

Photovoltaic (PV)

Glazing

Model

Battery

Inverter

\begin{abstract}
A B S T R A C T
Suspended particle device (SPD) glazing is an electrically actuated switchable glazing. It requires alternate current $(A C)$ power supply to switch from opaque to transparent state. To power this glazing using PV device requires inverter. Optimization of AC powered switchable SPD glazing using photovoltaic (PV) device has been evaluated using loss of power supply probability (LPSP). Electrically switchable direct current (DC) powered electrochromic glazing was also considered in this investigation as it doesn't need any inverter to couple with PV. It is concluded that behaviour of these glazings is the dominant factor in performance optimization outweighting than azimuthal orientation and inclination of PV.
\end{abstract}

๑) 2018 Elsevier Ltd. All rights reserved.

\section{Introduction}

Building consumes $40 \%-60 \%$ of total global energy due to heating load, cooling load and artificial lighting [1]. Significant heat loss and solar heat gain of a building can occur through windows. Smart switchable glazing has potential to reduce the incoming solar heat gain and control glare thereby permitting comfortable daylighting [2]. Electrically actuated smart switchable electrochromic (EC), liquid crystal (LC) and suspended particle device (SPD) glazings are attractive over non-electrically actuated thermochromic [3], thermotropic [4], gasochromic [5] and phase change material [6] glazings. Non-electrically actuated switchable glazings do not provide control of the glazing transmittance based on occupant choice. Electrically actuated electrochromic (EC) [7], liquid crystal (LC) [8] and suspended particle device (SPD) [9] glazing can be activated manually or can be switched contingent on internal conditions.

Alternating current (AC) powered electrically activated

\footnotetext{
* Corresponding author. Dublin Energy Lab, Dublin Institute of Technology, Dublin, Ireland.

E-mail addresses: a.ghosh@exeter.ac.uk, aritraghosh_9@yahoo.co.in (A. Ghosh).
}

switchable LC glazing can be twisted nematic, ferroelectric, guest host, and polymer dispersed liquid crystal (PDLC) types [8,10]. PDLC types are best suitable for glazing as it does not require polarizer to operate [11]. LC glazing creates haze during its opaque state [12], which has limited the scope of applications of LC. However, haze free LC glazing is under investigation $[13,14]$.

An EC glazing shown in Fig. 1 changes its state from "transparent" to "opaque" by a redox reaction in the presence of an applied direct current (DC) voltage typically from 0 to $5 \mathrm{~V}$ [15-17] reversible by inversion of electrical supply [18]. This colour change process requires less power at higher environment temperatures [19]. EC materials have potential to control visible [20-22] and near infra-red (NIR) solar radiation [23,24]. An EC glazing is opaque due to radiation absorption, rather than reflection. Thus an opaque EC glazing can be creating a heat source inside the building [25]. Five layer monolithic EC device [26], parallel double-layer-coated glass substrates joined by a polymer electrolyte EC [27], tungsten tri oxide $\left(\mathrm{WO}_{3}\right)$, prussian blue, polyvinyl butyral (PVB) electrolyte based laminated [18] and low cost polymer-foil-based laminated EC $[7,28]$ are the major available EC glazing device.

SPD films are plastics containing suspended needle or rod shaped dihydrocinchonidine bisulfite polyiodide particles are suspended [29-34]. In the presence of AC power supply this particles 


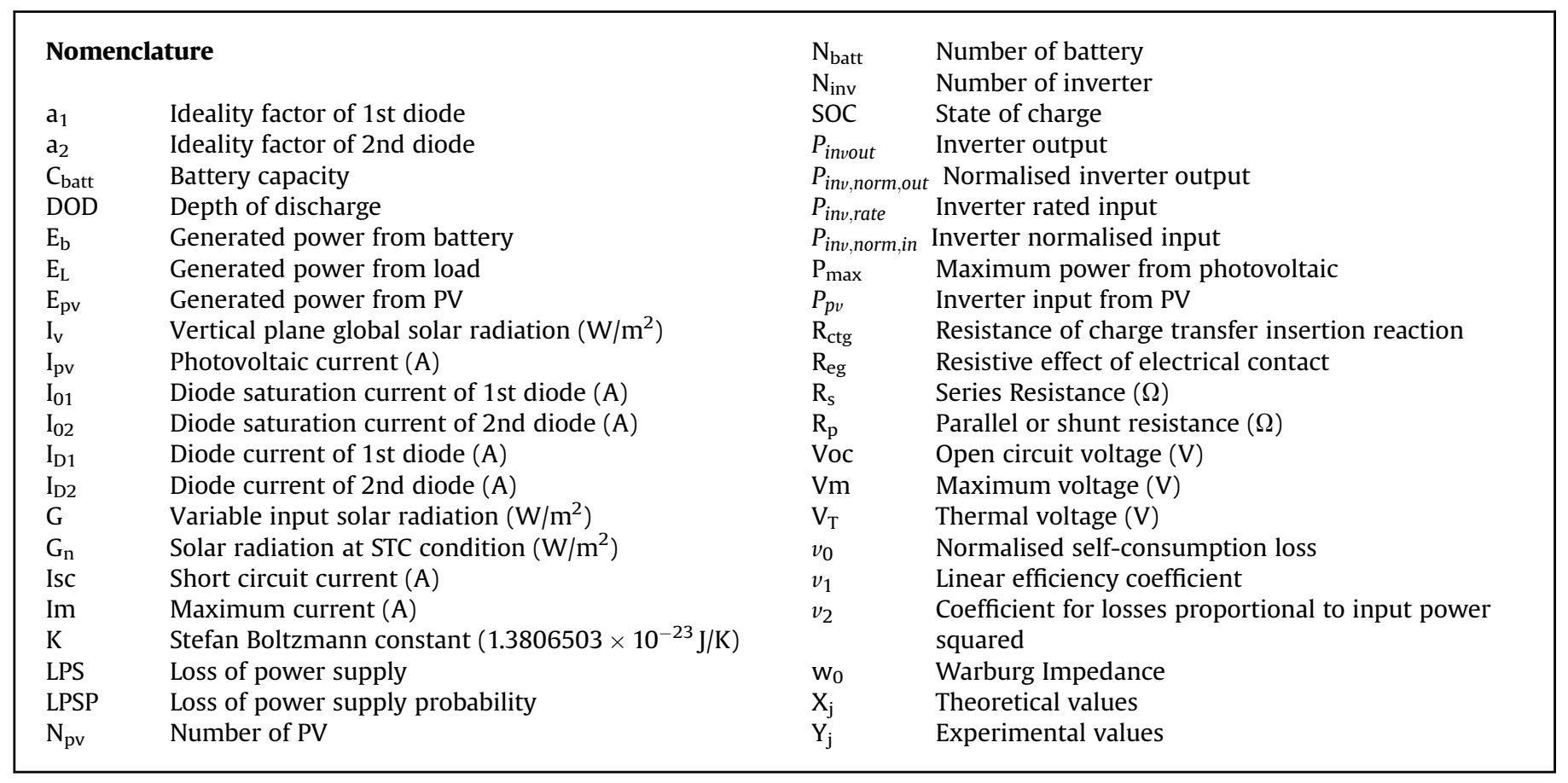

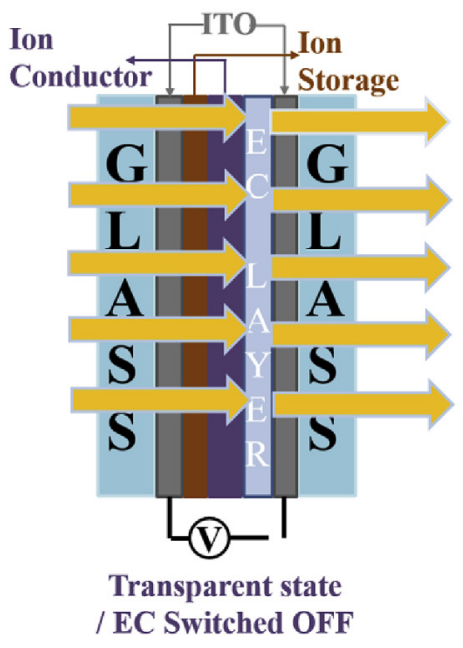

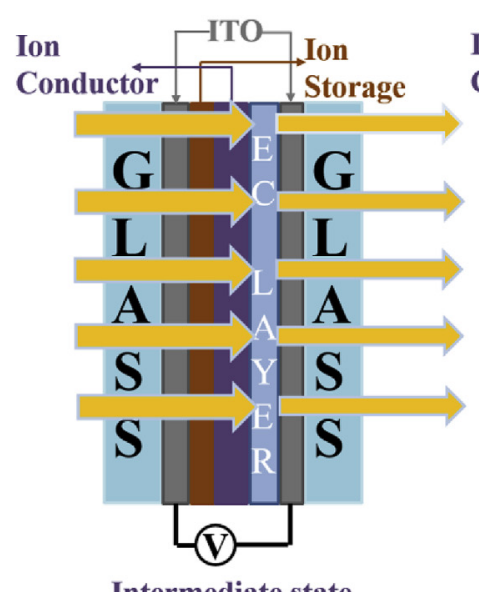

Intermediate state /EC Switched ON

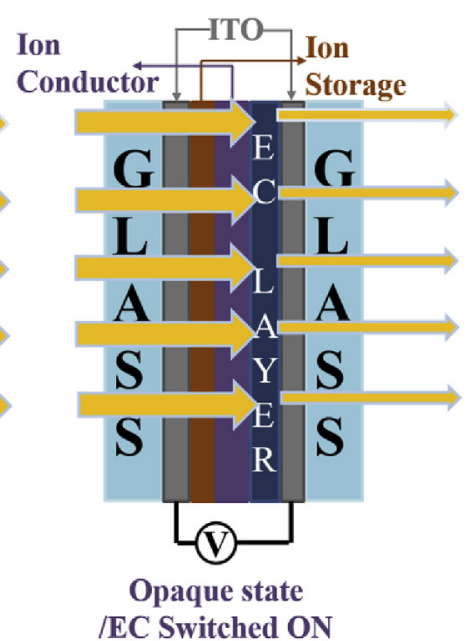

/EC Switched ON

Fig. 1. Electrochromic (EC) glazing showing transparent/bleached, intermediate and opaque/coloured state.

are orientated perpendicular to the substrate and allow light passing through it [35] as shown in Fig. 2. When unpowered, SPD particles oriented randomly due to Brownian motion and absorbed or reflect lights. The SPD glazing sample was considered in this work changes transmission from $5 \%$ to $55 \%$ in the presence of $110 \mathrm{~V}$, $0.07 \mathrm{~W}$ AC power supply [35]. Outdoor test cell characterisation of SPD glazing suggest that this glazing can be incorporated with double [36] or vacuum glazing [37,38] in a low heat loss window with variable solar heat gain [39,40]. SPD glazing with 30\% transmission offers glare control throughout a day for clear sunny day with a useful daylight index [41].

Using integrated PV to power switchable windows gives a selfcontained autonomous unit installed [35] [42-44] without connection to an electrical power supply nor the engagement of specialized electrical installer. Both these factors reduce the installation and operating costs. PV powered SPD glazing requires an inverter for transformation of DC PV power. Proper sizing of inverter is an essential criterion for PV powered SPD glazing [35].

Battery energy storage [45] is part of a PV-powered glazing system. The energy required for switching is the solar energy accumulated prior to switching rather than merely the instantaneously available solar energy. The PV area required is thus smaller than would be the soil no battery storage was in place.

In this work, optimization between PV, battery and AC powered SPD glazing and DC powered EC glazing were carried out using loss of power supply probability (LPSP) methods. To date no studies have been reported on PV powered switchable glazing optimization using LPSP or any other optimization methods.

\section{Methodology}

\subsection{PV modelling}

One-diode [46,47] and two-diode models [48,49] have been 

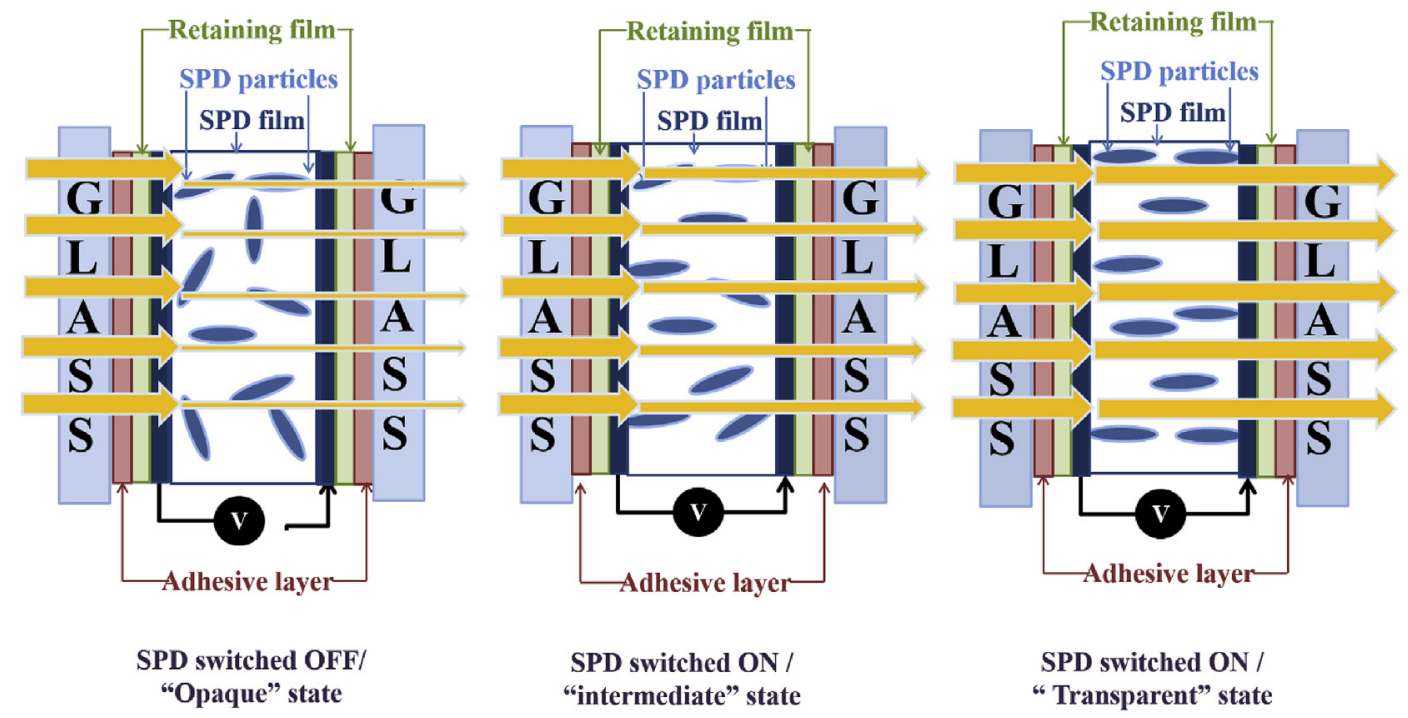

Fig. 2. Suspended particle device (SPD) glazing showing "transparent", intermediate and "opaque" state.

used to evaluate the maximum power output from a PV cell. A twodiode model in which the extra diode represents recombination carriers is used in this work giving the equivalent circuit shown in Fig. 3. The total current is given by;

$I=I_{p v}-I_{d 1}-I_{d 2}-I_{p}$

$$
\begin{aligned}
I= & I_{p v}-I_{01}\left[\exp \left(\frac{V+I R_{s}}{a_{1} V_{T 1}}\right)-1\right]-I_{02}\left[\exp \left(\frac{V+I R_{s}}{a_{2} V_{T 2}}\right)\right] \\
& -\left(\frac{V+I R_{S}}{R_{p}}\right)
\end{aligned}
$$

Where thermal voltage is given by

$V_{T}=\frac{N_{s} K T}{q}$

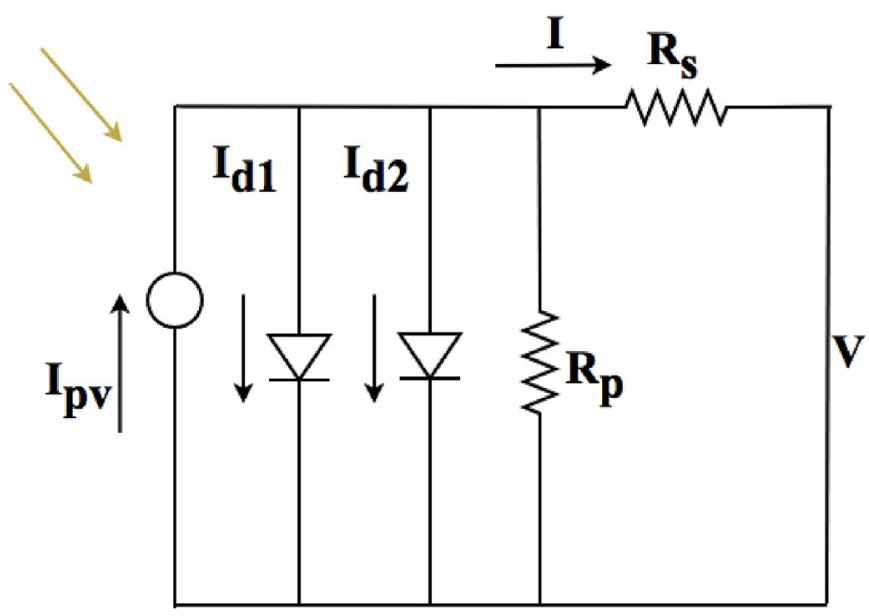

Fig. 3. Two-diode model of PV cell.
$I_{p v}=\left(I_{s c n}+K_{i}\right) \frac{G}{G_{n}}$

$I_{0}=\frac{\left(I_{s c n}+k_{i}\right) \Delta T}{\exp \left[\frac{V_{o c n}+k_{v} \Delta T}{a V_{T}}\right]-1}$

The power output from PV device is given by

$P_{p v}=V I$

Energy generated from PV device during time interval t to $\mathrm{T}$ (where $\mathrm{t}=$ day 1 and $\mathrm{T}=$ day 365 ) is given by

$E_{p v}=\int_{t}^{T} P_{p v} d t$

\subsection{Inverter output modelling}

Inverter efficiency varies as a function of an inverter input power [50-52].

$P_{\text {invout }}=P_{\text {inv, norm, out }} P_{\text {inv }, \text { rate }}$

$P_{\text {inv }, \text { norm }, \text { out }}=v_{0}+v_{1} P_{\text {inv, norm, in }}+v_{2} P_{\text {in } v, \text { norm }, \text { in }}^{2}$

$P_{\text {in }, \text { norm }, \text { in }}=\frac{P_{p v}}{P_{\text {inv,rate }}}$

The instantaneous inverter efficiency is given by

$\eta_{\text {inv }}=\frac{P_{\text {in } v, \text { norm }, \text { out }}}{P_{\text {in }, \text { norm, in }}}$

Obtained energy after inverter during time interval t to $\mathrm{T}$ (where $\mathrm{t}=$ day 1 and $\mathrm{T}=$ day 365 ) is given by 
$E_{i n v}=\int_{t}^{T} E_{p v} \eta_{i n v} d t$.

\subsection{Battery model}

Charging a battery using PV source system is neither a constant current source nor a constant voltage source [53,54]. Thus, a nonlinear battery storage model is used $[55,56]$ where;

$V_{b}=\varepsilon_{0}+(a \times S O C)+\left(R_{\text {int }} \times I_{b a t}\right)$

Here $V_{b}$ is the battery voltage for one element $\varepsilon_{0}$ is the battery equilibrium voltage, $S O C$ is the state of charge of the battery, the parameter relates the voltage with the state of charge. For accurate calculation, knowledge of the SOC of a battery is necessary [57]. $\mathrm{SOC}_{0}$ is the battery SOC of the starting point; t 0 and $\mathrm{t}$ are the time of the starting point and the time of interest, respectively, $\mathrm{C}_{\text {batt }}$ is the battery capacity, $\mathrm{I}_{\text {bat }}$ is the battery current. Eq. (14) represents the calculation of battery SOC for ideal batteries.

$S O C=S O C_{0}+\int_{t_{0}}^{t} \frac{I_{b a t}}{C_{b a t t}} d \tau$

Energy stored in a battery during time interval $t$ to $\mathrm{T}$ (where $\mathrm{t}=$ day 1 and $\mathrm{T}=$ day 365 ) is given by

$E_{b}=\int_{t}^{T} S O C \cdot C_{b a t t} d t$

\subsection{Glazing model}

Fig. 4 shows the complete circuit diagram of PV powered SPD and EC glazing. SPD [34] and EC [58] both glazing can be represented by using Randles circuit. This circuit contains the resistance for the charge transfer insertion $\left(R_{c t g}\right)$, double-layer capacitor $\left(C_{d l g}\right)$, resistance for electrical contacts $\left(R_{\mathrm{eg}}\right)$, and Warburg impedance $\left(w_{0}\right)$ to consider diffusion of charges. In this circuit, an AC powered SPD glazing is considered as an AC load whereas DC powered EC is considered as DC load. Generated power from PV-inverter system supply power to the glazing. Excess power charges the battery.
During no sunshine period, glazing is powered from battery.

$$
\begin{aligned}
& P_{\text {glazing }}=\left(\frac{v_{0}+v_{1} P_{\text {inv }, \text { norm }, \text { in }}+v_{2} P_{\text {inv,norm, in }}^{2}}{P_{p v} / P_{\text {in }, \text { rate }}}\right) \times \\
& {\left[V \left\{I_{p v}-I_{01}\left(\exp \left(\frac{V+I R_{S}}{a_{1} V_{T 1}}\right)-1\right)-I_{02}\left(\exp \left(\frac{V+I R_{S}}{a_{2} V_{T 2}}\right)-1\right)\right.\right.} \\
& \left.\left.-\left(\frac{V+I R_{S}}{R_{p}}\right)\right\}\right]
\end{aligned}
$$

Required energy demand for glazing for time interval t to $\mathrm{T}$ (where $\mathrm{t}=$ day 1 and $\mathrm{T}=365$ ) is given by

$E_{L}=\int_{t}^{T} P_{\text {glazing }} d t$

\subsection{LPSP model}

For a reliable hybrid energy systems the loss of power supply probability (LPSP) is defined by a number between 0 and 1 [59]. An LPSP of 1 indicates that the load will never be satisfied and an LPSP of 0 indicates that the load will be always satisfied. In this work, load is the glazing demand which is essential to remain the SPD glazing fully transparent state and EC glazing fully opaque state. For a specified elapsed period, $T$ (one year in this study), LPSP is defined by

$\operatorname{LPSP}(t)=\frac{\sum_{t=1}^{T} \operatorname{LPS}(t)}{\sum_{t=1}^{T} E_{L}(t)}$

Where loss of power supply (LPS) can be found from equation (19). Generated energy from PV $\left(E_{p v}\right)$ less than the load energy demand produces LPS. LPSP was calculated as shown in the flow diagram in Fig. 5.

$\left.\operatorname{LPS}(t)=E_{\text {load }}(t)-\left\{E_{p v}(t)+E_{b}(t-1)-(S O C) C_{\text {batt }} N_{\text {batt }}\right)\right\} \eta_{\text {inv }}$

Excess power generated from PV after meeting the demand of SPD glazing, charges the battery. This battery will supply power in the night time to keep SPD fully transparent. The battery in the

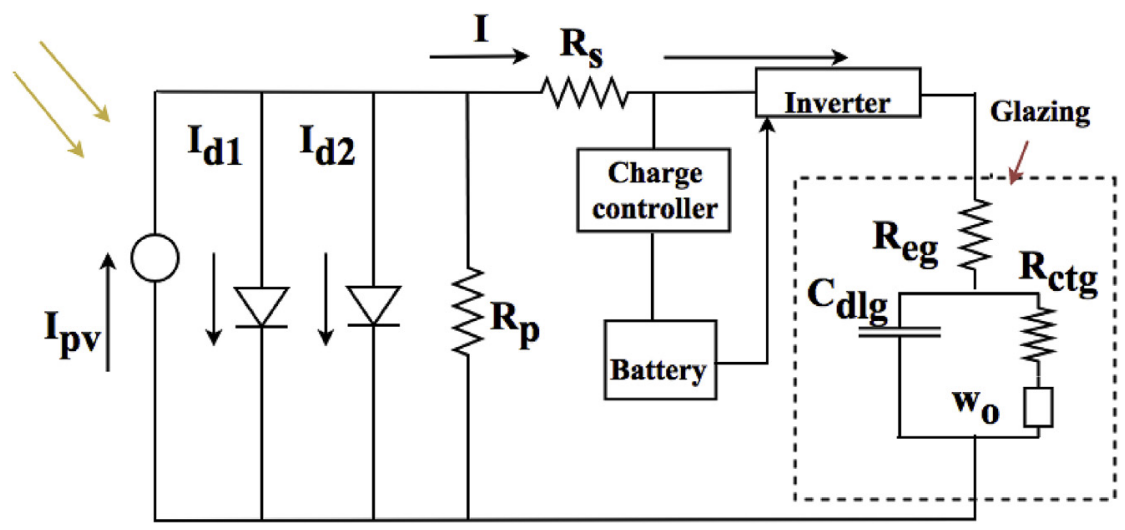

Fig. 4. Electrical circuit connection PV, charge controller, inverter, battery, glazing (glazing circuit represents both SPD and EC glazing). 


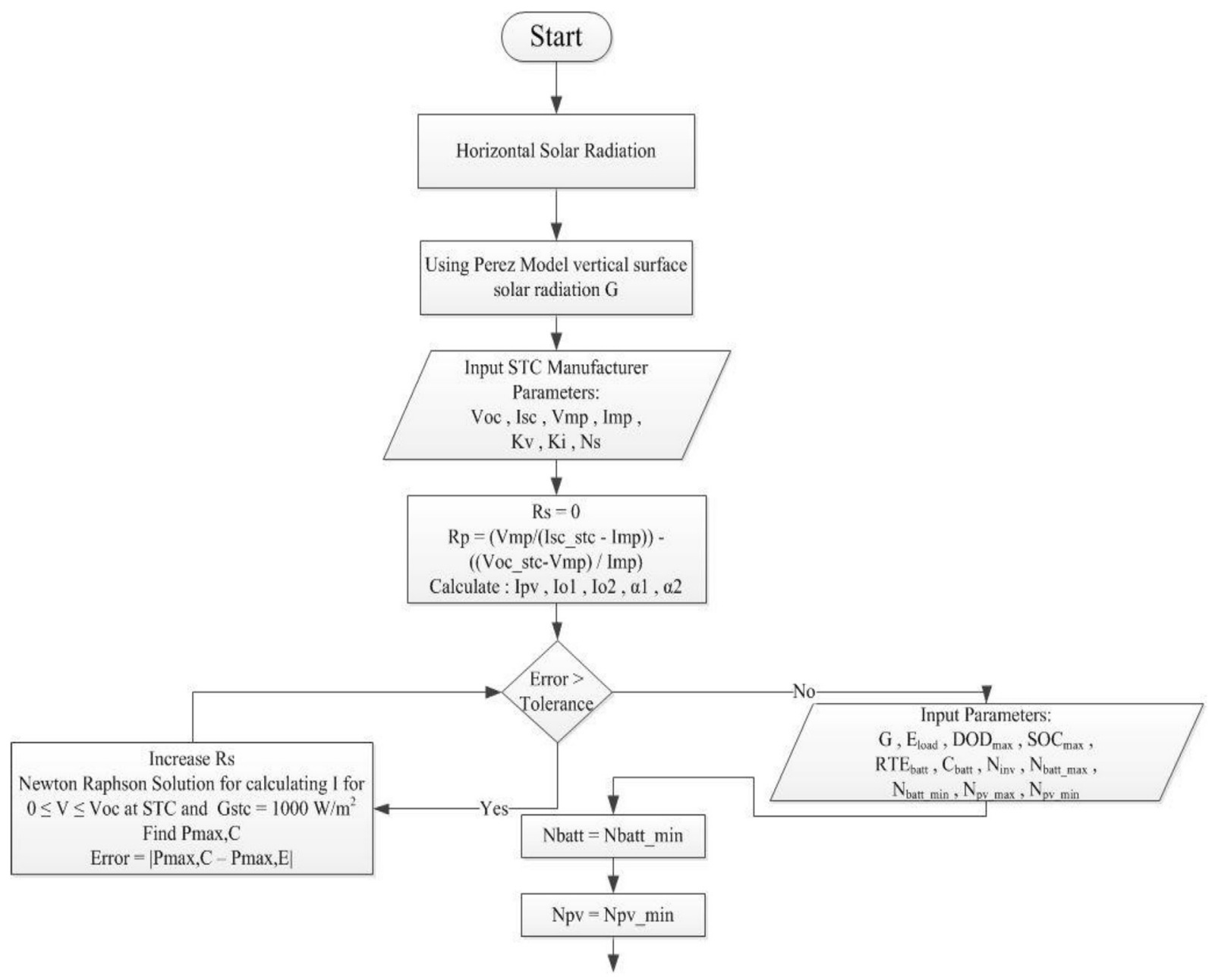

Fig. 5. Flow diagram for LPSP method.

system stores energy from PV during sun shine period and supply the energy to the SPD for night or overcast rainy condition. The PV module, inverter, battery and glazing specifications used are listed in Table 1, [35]. For this work, the glazing is assumed to have an active area of $1 \mathrm{~m}^{2}$ with a $0.5 \mathrm{~W}$ power consumption [35] and was kept switched on for $24 \mathrm{~h}$ and 365 days. Lead acid battery was selected for this work due to its high energy efficiency, low selfdischarge rate, and low up-front cost [45].

\section{Simulation validation}

The simulation model was compared with experimental measurements by Ref. [35]. Experimental work of PV powered SPD glazing was carried out in Dublin, Ireland $\left(53.34^{\circ} \mathrm{N}, 6.25^{\circ} \mathrm{W}\right)$ from 1st of May to 1st July 2014. Fig. 6 (a) shows that the PV double diode PV model predicted power output closely match to experimental measurements. Fig. 6 (b) shows the simulated inverter outputs also closely agreed with experiment data. For an SPD glazing powered by PV evaluated experimentally by Ref. [35] as shown in Fig. 6c, available output from inverter was $8.9 \mathrm{kWh}$ for a clear sunny day, without battery storage $8.42 \mathrm{kWh}$ power was unused and inverter losses were $53 \%$. Deviation of experimental and theoretical results were evaluated using root mean square percent deviation. Following expression was used to evaluate percentage deviation. Deviation for PV power generation and SPD power consumption (Figure c) was only $0.95 \%$.

$$
e=\sqrt{\frac{\sum_{t=1}^{n}\left(\frac{X_{j}-Y_{j}}{X_{j}}\right)^{2}}{n}}
$$

\section{Results \& discussions}

To obtain optimise low LPSP simulation work had been done varying battery capacity and PV power. Three different types of inverters were chosen. A dynamic type where output varies with solar radiation, a static 0.9 efficiency inverter for any solar radiation and a type where inverter efficiency was 1 . Last type can be considered for EC glazing (as shown in Fig. 9) as EC glazing obviates need of any inverter.

Fig. 7 illustrates effect of different PV and battery combination on LPSP. Required LPSP varied from 0.6 to 0.74 , due to the poor inverter performance. Higher PV rating matches closer to the inverter rating which creates less power loss and thus LPSP is low compared to lower rated PV.

Fig. 8 shows the PV and battery combinations with an inverter with a constant $90 \%$ efficiency. A constant efficiency inverter always provided higher output, which met the SPD glazing power requirement demand with less LPSP.

In Fig. 9 illustrates the LPSP for a 100\% efficient inverter which 


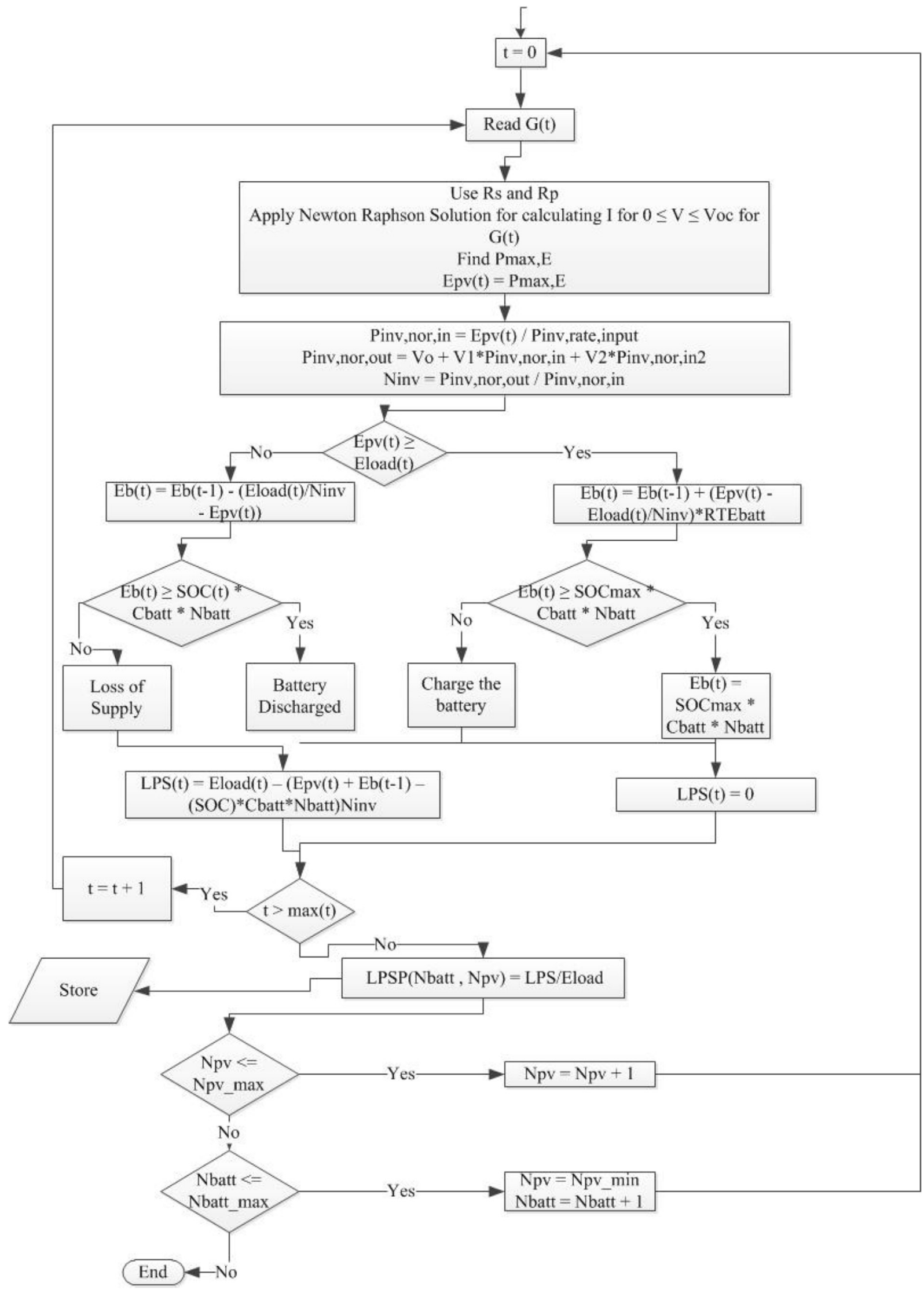

Fig. 5. (continued). 
Table 1

Specifications of system components.

\begin{tabular}{|c|c|c|}
\hline \multirow[t]{8}{*}{ Polycrystalline PV module } & Maximum Power $\left(\mathrm{P}_{\mathrm{m}}\right)$ & $40 \mathrm{~W}$ \\
\hline & Open circuit voltage $\left(\mathrm{V}_{\mathrm{oc}}\right)$ & $21.6 \mathrm{~V}$ \\
\hline & Short circuit current $\left(\mathrm{I}_{\mathrm{sc}}\right)$ & $2.51 \mathrm{~A}$ \\
\hline & Maximum voltage $\left(\mathrm{V}_{\mathrm{m}}\right)$ & $17.8 \mathrm{~V}$ \\
\hline & Maximum current $\left(\mathrm{I}_{\mathrm{m}}\right)$ & $2.25 \mathrm{~A}$ \\
\hline & Efficiency $(\eta)$ & $16-16.5 \%$ \\
\hline & Area $(A)$ & $0.52 \mathrm{~m} \times 0.66 \mathrm{~m}\left(0.3432 \mathrm{~m}^{2}\right)$ \\
\hline & Cost & 550 euro $/ 0.3434 \mathrm{~m}^{2}$ \\
\hline \multirow[t]{5}{*}{ Inverter } & Max input voltage & $12 \mathrm{~V}$ \\
\hline & Max input current & $16 \mathrm{~A}$ \\
\hline & Rated output voltage & $230 \mathrm{~V}$ \\
\hline & Max output current & $0.89 \mathrm{~A}$ \\
\hline & Cost & 150 euro \\
\hline \multirow[t]{3}{*}{ Lead acid battery } & Battery voltage & $12 \mathrm{~V}$ \\
\hline & Battery capacity & $12 \mathrm{AH}$ \\
\hline & cost & 35 euro \\
\hline \multirow[t]{3}{*}{ SPD glazing } & Power requirement & $0.07 \mathrm{~W}, 100 \mathrm{~V}$ (transparent) \\
\hline & & $0 \mathrm{~V}$ (opaque) \\
\hline & Active area & $0.0345 \mathrm{~m}^{2}$ \\
\hline
\end{tabular}

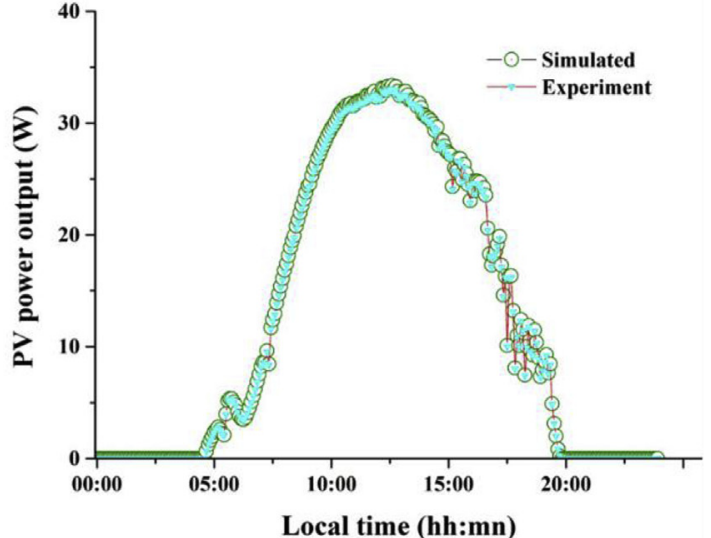

(a)

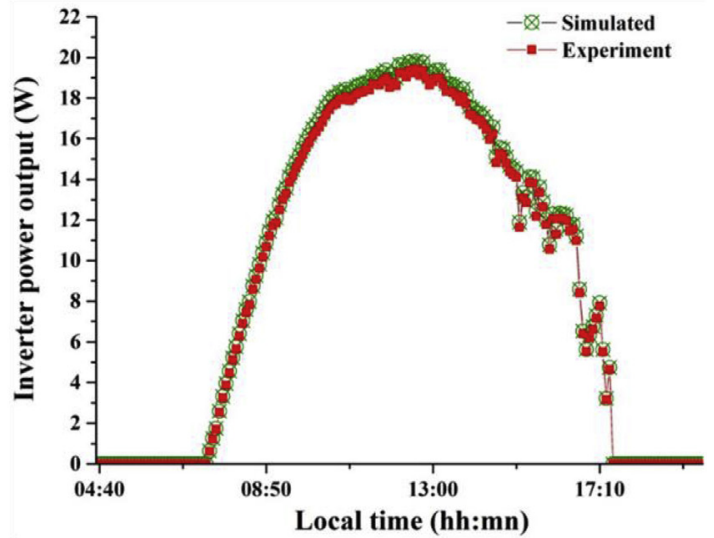

(b)

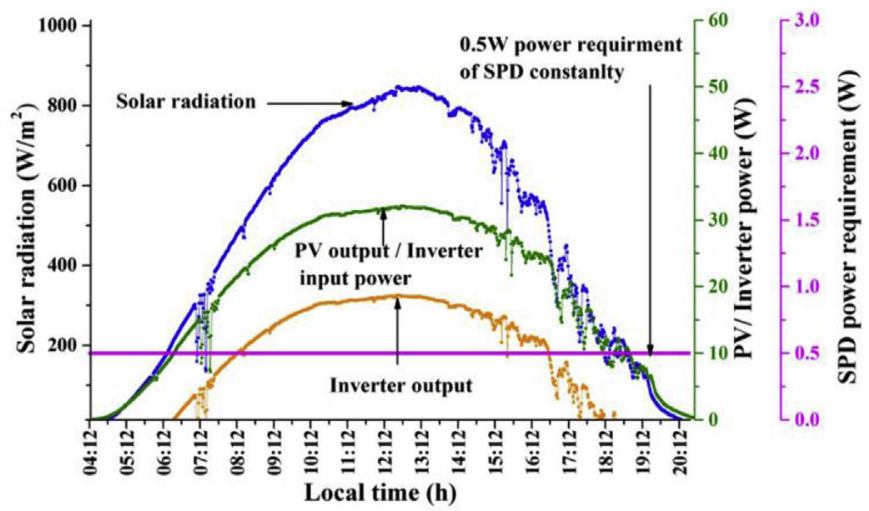

(c)

Fig. 6. (a) Comparison of PV output power from simulation and experiment, (b) Comparison of inverter output from simulation and experiment (c) diurnal performance of $40 \mathrm{~W}_{\mathrm{p}} \mathrm{PV}$ powered $0.5 \mathrm{~W}$ SPD glazing.

provides all PV power output directly to the SPD glazing with no losses. As SPD works with only AC and a $100 \%$ inverter efficiency is not possible in reality, this case can be considered as equivalent to a DC powered EC glazing. For an EC glazing powered by $4 \mathrm{~W}$ PV with only $12 \mathrm{AH}$ battery had the highest LPSP at 0.05 .
To obtain transparent state SPD glazing needs high voltage, low AC power. Whilst, EC glazing needs low voltage, low DC power to obtain opaque state. It is evident from this work that inverter requirement for PV-powered SPD glazing causes higher LPSP and enhances the number of battery storage. As SPD needs higher 


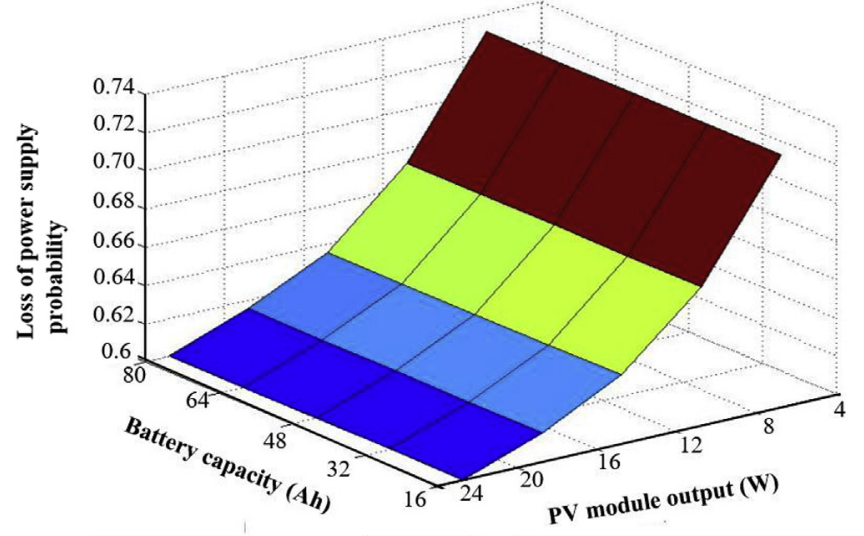

Fig. 7. LPSP for different PV module output and different battery capacity with variable inverter efficiency.

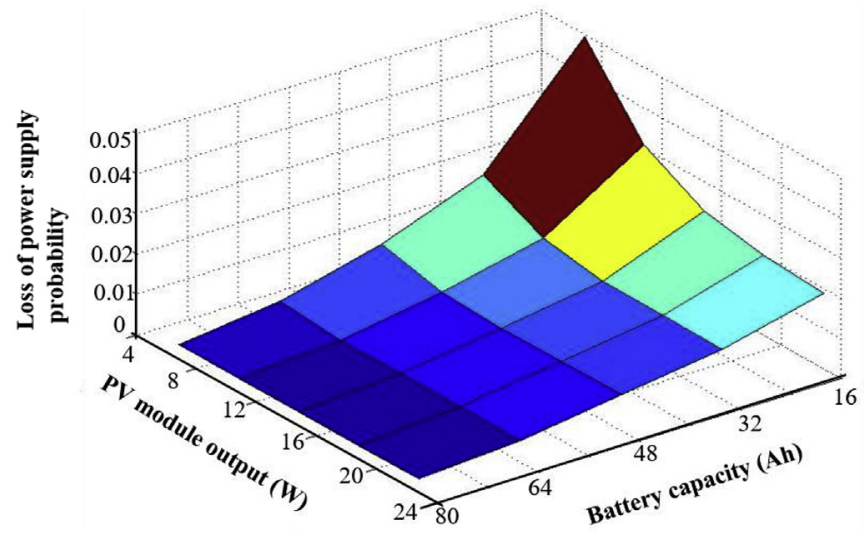

Fig. 8. LPSP for different PV outputs and different battery capacity with a constant inverter efficiency of $90 \%$.

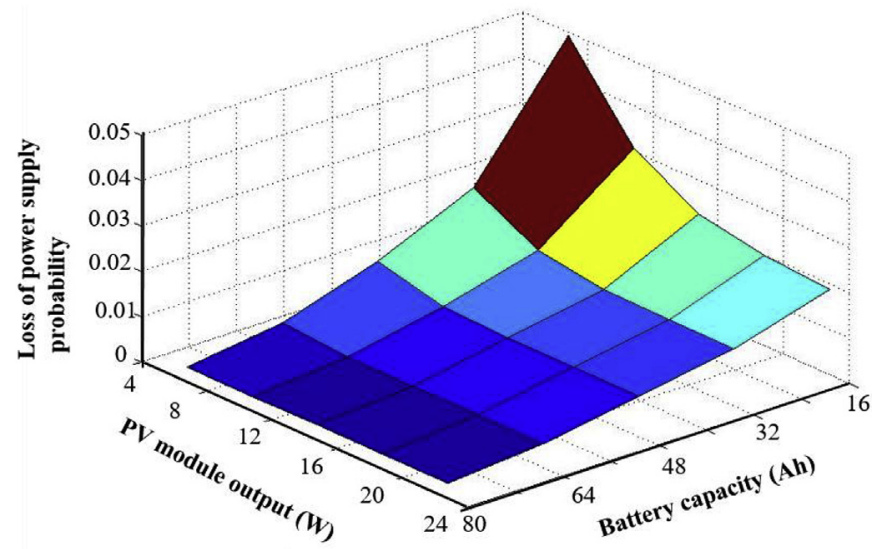

Fig. 9. LPSP for different PV module output and different battery capacity with constant inverter efficiency of $100 \%$ or a DC glazing.

voltage to modulate its transparency, side-by-side PV-SPD structure is promising while PV area should be large enough to generate this high voltage. Tandem structure PV -SPD is only possible if low driving voltage SPD is available. Tandem PV-EC structure is suitable due to its low voltage and no power inversion requirement.

\section{Conclusions}

Energy saving potential, control over switchable state and simpler installation make switchable glazing a potential choice for retrofit and new zero energy building. However, direct powering for these type of glazing from grid add to building's energy cost [35] [60]. Thus, PV powered electrically activated glazing is promising as they can transform an ordinary building to smart or zero energy building [2]. Using LPSP method optimization of PV powered SPD was conducted. Experimentally it was reported before that SPD glazing needs AC power to actuate which force to use inverter. Addition of inverter creates losses, which can be reduced using similar sizing area PV and inverter. In this work, PV powered SPD throughout the day and night and battery system was there to store excess energy from PV. Though EC needs power to obtain opaque state, no inverter requirement consume less PV power (thus less PV area required). Low power rated power electronics (low power rated inverter) are highly recommended for this PV-SPD integration. To enable low LPSP from PV powered SPD, investigations are required on low driving voltage SPD.

Switchable EC and SPD are primarily required to control the entering solar heat gain inside a room. SPD and EC both have potential to offer controllable intermediate states. EC becomes opaque in the presence of power supply where as SPD becomes opaque without power supply. Thus during the daytime, to control solar gain, EC can use PV power directly whereas power can be stored for SPD. Although, power consumption and changes of transparency for both glazing depend on occupants demand and behaviour, based on glazings operating performance it is clear that battery storage is essential for both glazing and SPD needs higher number of battery storage.

\section{Acknowledgements}

The work described in this paper was supported by the Graduate Research Education Programme of the Higher Education Authority, Ireland.

\section{References}

[1] F. Favoino, M. Overend, Q. Jin, The optimal thermo-optical properties and energy saving potential of adaptive glazing technologies, Appl. Energy 156 (2015) 1-15, https://doi.org/10.1016/j.apenergy.2015.05.065.

[2] A. Ghosh, B. Norton, Advances in switchable and highly insulating autonomous (self-powered) glazing systems for adaptive low energy buildings, Renew. Energy 126 (2018) 1003-1031, https://doi.org/10.1016/ j.renene.2018.04.038.

[3] M.M. Seyfouri, R. Binions, Sol-gel approaches to thermochromic vanadium dioxide coating for smart glazing application, Sol. Energy Mater. Sol. Cells 159 (2017) 52-65, https://doi.org/10.1016/j.solmat.2016.08.035.

[4] A.C. Gladen, J.H. Davidson, S.C. Mantell, Selection of thermotropic materials for overheat protection of polymer absorbers, Sol. Energy 104 (2014) 42-51, https://doi.org/10.1016/j.solener.2013.10.026.

[5] W. Feng, L. Zou, G. Gao, G. Wu, J. Shen, W. Li, Gasochromic smart window: optical and thermal properties, energy simulation and feasibility analysis, Sol. Energy Mater. Sol. Cells 144 (2016) 316-323, https://doi.org/10.1016/ j.solmat.2015.09.029.

[6] C. Liu, Y. Wu, D. Li, Y. Zhou, Z. Wang, X. Liu, Effect of PCM thickness and melting temperature on thermal performance of double glazing units, J. Build. Eng. 11 (2017) 87-95, https://doi.org/10.1016/j.jobe.2017.04.005.

[7] C.G. Granqvist, I. Bayrak Pehlivan, G.A. Niklasson, Electrochromics on a roll: web-coating and lamination for smart windows, Surf. Coating. Technol. (2017) 6-11, https://doi.org/10.1016/j.surfcoat.2017.08.006.

[8] A. Ghosh, B. Norton, T.K. Mallick, Solar Energy Materials and Solar Cells Daylight characteristics of a polymer dispersed liquid crystal switchable glazing, Sol. Energy Mater. Sol. Cells 174 (2018) 572-576, https://doi.org 10.1016/j.solmat.2017.09.047.

[9] A. Ghosh, B. Norton, A. Duffy, Behaviour of a SPD switchable glazing in an outdoor test cell with heat removal under varying weather conditions, Appl. Energy 180 (2016) 695-706, https://doi.org/10.1016/j.apenergy.2016.08.029.

[10] A. Ghosh, T.K. Mallick, Evaluation of colour properties due to switching behaviour of a PDLC glazing for adaptive building integration, Renew. Energy 
120 (2018) 126-133, https://doi.org/10.1016/j.renene.2017.12.094.

[11] G. Macrelli, Optical characterization of commercial large area liquid crysta devices, Sol. Energy Mater. Sol. Cells 39 (1995) 123-131, https://doi.org 10.1016/0927-0248(95)00044-5.

[12] A. Ghosh, T.K. Mallick, Evaluation of optical properties and protection factors of a PDLC switchable glazing for low energy building integration, Sol. Energy Mater. Sol. Cells (2017), https://doi.org/10.1016/j.solmat.2017.10.026, 0-1.

[13] D. Jung, W. Choi, J.-Y. Park, K.B. Kim, N. Lee, Y. Seo, H.S. Kim, N.K. Kong Inorganic gel and liquid crystal based smart window using silica sol-gel process, Sol. Energy Mater. Sol. Cells 159 (2017) 488-495, https://doi.org/ 10.1016/j.solmat.2016.10.001.

[14] S. Park, J.W. Hong, Polymer dispersed liquid crystal film for variabletransparency glazing, Thin Solid Films 517 (2009) 3183-3186, https:/ doi.org/10.1016/j.tsf.2008.11.115.

[15] C.M. Lampert, Electrochromic materials and devices for energy efficient windows, Sol. Energy Mater. 11 (1984) 1-27, https://doi.org/10.1016/01651633(84)90024-8.

[16] C.G. Granqvist, Electrochromic devices, J. Eur. Ceram. Soc. 25 (2005) 2907-2912, https://doi.org/10.1016/j.jeurceramsoc.2005.03.162.

[17] C.G. Granqvist, P.C. Lansåker, N.R. Mlyuka, G.A. Niklasson, E. Avendaño, Progress in chromogenics: new results for electrochromic and thermochromic materials and devices, Sol. Energy Mater. Sol. Cells 93 (2009) 2032-2039, https://doi.org/10.1016/j.solmat.2009.02.026.

[18] A. Kraft, M. Rottmann, Properties, performance and current status of the laminated electrochromic glass of Gesimat, Sol. Energy Mater. Sol. Cells 93 (2009) 2088-2092, https://doi.org/10.1016/j.solmat.2009.05.010.

[19] A. Ghosh, B. Norton, A. Duffy, Calculation of colouration voltage for a multifunctional glazing powered by photovoltaic, Conf. Pap. (2013) 3434-3436. http://arrow.dit.ie/engschcivcon/66.

[20] A. Piccolo, A. Pennisi, F. Simone, Daylighting performance of an electrochromic window in a small scale test-cell, Sol. Energy 83 (2009) 832-844, https://doi.org/10.1016/j.solener.2008.11.013.

[21] A. Piccolo, F. Simone, Effect of switchable glazing on discomfort glare from windows, Build. Environ. 44 (2009) 1171-1180, https://doi.org/10.1016/ j.buildenv.2008.08.013.

[22] A. Piccolo, F. Simone, Performance Requirements for Electrochromic Smart Window, Elsevier, 2015, https://doi.org/10.1016/j.jobe.2015.07.002.

[23] A.P. Schuster, D. N.G.U.Y.E. N, O. Caporaletti, Solid state E L E C T R O C H R O M I C, Infrared Switchable Windows 13 (1986) 153-160.

[24] C. Lampert, Smart switchable glazing for solar energy and daylight control, Sol. Energy Mater. Sol. Cells 52 (1998) 207-221, https://doi.org/10.1016/ S0927-0248(97)00279-1.

[25] Y. Fang, P.C. Eames, Thermal performance of an electrochromic vacuum glazing, Energy Convers. Manag. 47 (2006) 3602-3610, https://doi.org/ 10.1016/j.enconman.2006.03.016.

[26] N.L. Sbar, L. Podbelski, H.M. Yang, B. Pease, Electrochromic dynamic windows for office buildings, Int. J. Sustain. Built Environ. 1 (2012) 125-139, https:/ doi.org/10.1016/j.ijsbe.2012.09.001.

[27] M. Zinzi, Office worker preferences of electrochromic windows: a pilot study, Build. Environ. 41 (2006) 1262-1273, https://doi.org/10.1016 j.buildenv.2005.05.010.

[28] A. Azens, E. Avendaño, J. Backholm, L. Berggren, G. Gustavsson, R. Karmhag, G.A. Niklasson, A. Roos, G.G. Granqvist, Flexible foils with electrochromic coatings: science, technology and applications, Mater. Sci. Eng. B Solid-State Mater. Adv. Technol. 119 (2005) 214-223, https://doi.org/10.1016 j.mseb.2004.12.085

[29] A. Ghosh, B. Norton, A. Duffy, Effect of sky conditions on light transmission through a suspended particle device switchable glazing, Sol. Energy Mater. Sol. Cells 160 (2017) 134-140, https://doi.org/10.1016/j.solmat.2016.09.049.

[30] A. Ghosh, B. Norton, Durability of switching behaviour after outdoor exposure for a suspended particle device switchable glazing, Sol. Energy Mater. Sol. Cells 163 (2017) 178-184, https://doi.org/10.1016/j.solmat.2017.01.036.

[31] A. Ghosh, B. Norton, Interior colour rendering of daylight transmitted through a suspended particle device switchable glazing, Sol. Energy Mater. Sol. Cells 163 (2017) 218-223, https://doi.org/10.1016/j.solmat.2017.01.041.

[32] D. Barrios, R. Vergaz, J.M. Sánchez-Pena, B. García-Cámara, C.G. Granqvist, G.A. Niklasson, Simulation of the thickness dependence of the optical properties of suspended particle devices, Sol. Energy Mater. Sol. Cells 143 (2015) 613-622, https://doi.org/10.1016/j.solmat.2015.05.044.

[33] D. Barrios, R. Vergaz, J.M. Sanchez-Pena, C.G. Granqvist, G.A. Niklasson, Toward a quantitative model for suspended particle devices: optical scattering and absorption coefficients, Sol. Energy Mater. Sol. Cells 111 (2013) 115-122, https://doi.org/10.1016/j.solmat.2012.12.012.

[34] R. Vergaz, J.M. Sánchez-Pena, D. Barrios, C. Vázquez, P. Contreras-Lallana, Modelling and electro-optical testing of suspended particle devices, Sol. Energy Mater. Sol. Cells 92 (2008) 1483-1487, https://doi.org/10.1016/ j.solmat.2008.06.018.
[35] A. Ghosh, B. Norton, A. Duffy, First outdoor characterisation of a PV powered suspended particle device switchable glazing, Sol. Energy Mater. Sol. Cells 157 (2016) 1-9, https://doi.org/10.1016/j.solmat.2016.05.013.

[36] A. Ghosh, B. Norton, A. Duffy, Measured overall heat transfer coefficient of a suspended particle device switchable glazing, Appl. Energy 159 (2015) 362-369, https://doi.org/10.1016/j.apenergy.2015.09.019.

[37] A. Ghosh, B. Norton, A. Duffy, Effect of sky clearness index on transmission of evacuated (vacuum) glazing, Renew. Energy 105 (2017) 160-166, https:// doi.org/10.1016/j.renene.2016.12.056.

[38] A. Ghosh, B. Norton, A. Duffy, Measured thermal \& daylight performance of an evacuated glazing using an outdoor test cell, Appl. Energy 177 (2016) 196-203, https://doi.org/10.1016/j.apenergy.2016.05.118.

[39] A. Ghosh, B. Norton, A. Duffy, Measured thermal performance of a combined suspended particle switchable device evacuated glazing, Appl. Energy 169 (2016) 469-480, https://doi.org/10.1016/j.apenergy.2016.02.031.

[40] A. Ghosh, B. Norton, A. Duffy, Effect of atmospheric transmittance on performance of adaptive SPD-vacuum switchable glazing, Sol. Energy Mater. Sol. Cells 161 (2017) 424-431, https://doi.org/10.1016/j.solmat.2016.12.022.

[41] A. Ghosh, B. Norton, A. Duffy, Daylighting performance and glare calculation of a suspended particle device switchable glazing, Sol. Energy 132 (2016) 114-128, https://doi.org/10.1016/j.solener.2016.02.051.

[42] S.K. Deb, A novel electrophotographic system, Appl. Optic. 8 (1969) 192-195.

[43] A. Cannavale, G.E. Eperon, P. Cossari, A. Abate, H.J. Snaith, G. Gigli, Perovskite photovoltachromic cells for building integration, Energy Environ. Sci. 8 (2015) 1578-1584, https://doi.org/10.1039/C5EE00896D.

[44] L.M. Huang, C.W. Hu, H.C. Liu, C.Y. Hsu, C.H. Chen, K.C. Ho, Photovoltaic electrochromic device for solar cell module and self-powered smart glass applications, Sol. Energy Mater. Sol. Cells 99 (2012) 154-159, https://doi.org/ 10.1016/j.solmat.2011.03.036.

[45] X. Hu, C. Zou, C. Zhang, Y. Li, Technological developments in batteries: a survey of principal roles, types, and management needs, IEEE Power Energy Mag. 15 (2017) 20-31, https://doi.org/10.1109/MPE.2017.2708812.

[46] W. De Soto, S.A. Klein, W.A. Beckman, Improvement and validation of a model for photovoltaic array performance, Sol. Energy 80 (2006) 78-88, https:// doi.org/10.1016/j.solener.2005.06.010.

[47] T.O. Saetre, O.M. Midtgård, G.H. Yordanov, A new analytical solar cell I-V curve model, Renew. Energy 36 (2011) 2171-2176, https://doi.org/10.1016/ j.renene.2011.01.012.

[48] S.M. Hassan Hosseini, A.A. Keymanesh, Design and construction of photovoltaic simulator based on dual-diode model, Sol. Energy 137 (2016) 594-607, https://doi.org/10.1016/j.solener 2016.09.001.

[49] A. Zegaoui, P. Petit, M. Aillerie, J.P. Sawicki, A.W. Belarbi, M.D. Krachai, J.P. Charles, Photovoltaic cell/panel/array characterizations and modeling considering both reverse and direct modes, Energy Procedia 6 (2011) 695-703, https://doi.org/10.1016/j.egypro.2011.05.079.

[50] K. Peippo, P.D. Lund, Optimal sizing of solar array and inverter in gridconnected photovoltaic systems, Sol. Energy Mater. Sol. Cells 32 (1994) 95-114, https://doi.org/10.1016/0927-0248(94)90259-3.

[51] J.D. Mondol, Y.G. Yohanis, B. Norton, Optimal sizing of array and inverter for grid-connected photovoltaic systems, Sol. Energy 80 (2006) 1517-1539, https://doi.org/10.1016/j.solener.2006.01.006.

[52] K. Peippo, P.D. Lund, Optimal sizing of grid-connected PV-systems for different climates and array orientations: a simulation study, Sol. Energy Mater. Sol. Cells 35 (1994) 445-451, https://doi.org/10.1016/0927-0248(94) 90172-4.

[53] X. Hu, S. Li, Y. Yang, Advanced machine learning approach for lithium-ion battery state estimation in electric vehicles, IEEE Trans. Transp. Electrif. 7782 (2015), https://doi.org/10.1109/TTE.2015.2512237, 1-1.

[54] X. Wu, X. Hu, S. Moura, X. Yin, V. Pickert, Stochastic control of smart home energy management with plug-in electric vehicle battery energy storage and photovoltaic array, J. Power Sources 333 (2016) 203-212, https://doi.org/ 10.1016/j.jpowsour.2016.09.157.

[55] A. Joyce, C. Rodrigues, R. Manso, Modelling a PV system, Renew. Energy 22 (2001) 275-280, https://doi.org/10.1016/S0960-1481(00)00031-8.

[56] W. Chen, H. Shen, B. Shu, H. Qin, T. Deng, Evaluation of performance of MPPT devices in PV systems with storage batteries, Renew. Energy 32 (2007) 1611-1622, https://doi.org/10.1016/j.renene.2006.06.009.

[57] S. Piller, M. Perrin, A. Jossen, Methods for state-of-charge determination and their applications, J. Power Sources 96 (2001) 113-120, https://doi.org/ 10.1016/S0378-7753(01)00560-2.

[58] J. Wang, J.M. Bell, I.L. Skryabin, Kinetics of Charge Injection in Sol - Gel Deposited WO, 1999, p. 56.

[59] B.S. Borowy, Z.M. Salameh, Methodology for optimally sizing the combination of a battery bank and PV array in a Wind/PV hybrid system, IEEE Trans. Energy Convers. 11 (1996) 367-373, https://doi.org/10.1109/60.507648.

[60] L. Winkless, One step closer to self-powered switchable glazing? Mater. Today 19 (2016) 370, https://doi.org/10.1016/j.mattod.2016.07.016. 